\title{
Acaricidal efficacy of topical formulation of fipronil in naturally infested dogs in Amazonic region, Brazil
}

\author{
Eficácia carrapaticida de fipronil tópico em cães naturalmente infestados na região amazônica, Brasil \\ Viviane Labs Fischer ${ }^{1}$; Maycon Junior Heidmann ${ }^{1}$; Eduardo Ferreira Faria ${ }^{1}$; Vanessa Garcia Rizzi²; \\ Gabrielle Nellis Bragaglia²; Cristiano Grisi do Nascimento ${ }^{3}$; Bruno Gomes de Castro ${ }^{1 *}$ \\ ${ }^{1}$ Instituto de Ciências da Saúde - ICS, Universidade Federal de Mato Grosso - UFMT, Sinop, MT, Brasil \\ ${ }^{2}$ Ourofino Agronegócio Ltda, Cravinhos, SP, Brasil \\ ${ }^{3}$ Convolution Antiparasitary Division, Ribeirão Preto, SP, Brasil
}

Received May 10, 2012

Accepted November 1, 2012

\begin{abstract}
This study was conducted to show the effectiveness of a novel formulation of fipronil in a spot-on formulation for the therapeutic and preventive control of Rhipicephalus sanguineus in naturally infested dogs. Ticks on all dogs were counted at the moment of treatment and weekly after treatment (therapeutic efficacy) or infestation (preventive efficacy). The profile of the therapeutic efficacy for Rhipicephalus sanguineus suggested that the formulation was able to control the Ixodid species for at least 42 days after the treatment.
\end{abstract}

Keywords: Therapeutic and preventive effectiveness, fipronil, Rhipicephalus sanguineus.

\section{Resumo}

Este estudo teve como objetivo avaliar a eficácia de uma nova formulação "spot-on" à base de fipronil na terapêutica e prevenção do parasitismo por Rhipicephalus sanguineus em cáes naturalmente infestados. Foi realizada contagem dos carrapatos no momento da aplicação do produto e semanalmente após o tratamento (eficácia terapêutica), bem como avaliando sua reinfestaçáo (eficácia preventiva). Perfis terapêuticos e preventivos sugerem que a formulação controla o parasitismo por $R$. sanguineus em cães por pelo menos 42 dias após o tratamento.

Palavras-chave: Eficácia terapêutica e preventiva, fipronil, Rhipicephalus sanguineus.

The brown dog tick or kennel tick Rhipicephalus sanguineus belongs to the Ixodidae family and has the dog as its natural host (WALKER, 1994). The control of $R$. sanguineus requires an integrated strategy, which should include environmental and on-animal treatments. Spot-on formulations provide easy use for the latter and a monthly dosing interval may support the prevention of the transmission of diseases to dogs and, potentially, to their owners. Active ingredients with high levels of efficacy against R. sanguineus include mainly fipronil formulations (HUNTER et al., 2011; PEREIRA et al., 2011).

In Brazil, several studies have described the therapeutic efficacy in dogs and other species naturally and experimentally infested with ticks and fleas (TANCREDI et al., 2009; PAIM et al., 2011), but no studies have tested the efficacy of Fipronil in dogs in the particular conditions of the Amazon region climate. It is necessary

*Corresponding author: Bruno Gomes de Castro

Hospital Veterinário, Universidade Federal de Mato Grosso - UFMT,

Av. Alexandre Ferronato, 1200, Setor Industrial, Sinop, MT, Brasil

e-mail: castrobg@ufmt.br to emphasize that the natural feature of the Rainforest, characterized by heavy rainfall, can affect the efficiency of topical formulations on the control of ticks' populations (GROSSCURT, 1993).

The purpose of this study was to demonstrate the efficacy of fipronil formulation FIPR 122 (Ourofino Animal Health, SP, Brazil) against $R$. sanguineus in the Brazilian Amazon region.

This study was carried out in households in the municipality of Sinop, State of Mato Grosso, Brazil, from June to August 2011. In the Amazon Region, this period represents the transition from the rainy to the dry seasons. A total of 50 healthy mongrels were selected and identified. In this study, animals naturally infested were used presenting a minimum of three ticks; in other words, infestation scale up to one (1), as suggested by Marchiondo et al. (2007).

Clinical evaluations of the animals were immediately performed before the treatment $(\mathrm{D} 0)$, after about ten minutes of the treatment (+10 D0), and, then, every following week $(\mathrm{D}+7, \mathrm{D}+14, \mathrm{D}+21$, $\mathrm{D}+28, \mathrm{D}+35$ and $\mathrm{D}+42)$. The scores of $R$. sanguineus immature and adult stages were also weekly evaluated until day +42 after treatment. 
Descriptive analyses were performed according to the scale of infestation as recommended by Marchiondo et al. (2007). The raw data of the ticks count was transformed in a natural logarithm of 10 (count +1 ). The data were analyzed using the analysis of variance test (ANOVA) followed by Student-Newman-Keuls test for means comparisons. The level of significance used was $\mathrm{p} \leq 0.05$. The threshold of $90 \%$ reduction in the counts of ticks in treated dogs compared to untreated ones was considered as of acceptable efficacy for tick control agents, as recommended by Marchiondo et al. (2007).

Results showed that, in all 50 dogs evaluated in the current study, the only Ixodid species present was Rhipicephalus sanguineus, as suggested by the identification keys by Barros-Battesti et al. (2006). All data concerning the 50 animals are shown in Table 1.

Regarding the progress of tick populations and evaluation of the acaricidal efficacy of the Fipronil formulation on the first day of the study, the evaluated animals presented a mean of 13.88 ticks. Animals infested with the minimum recommended amount of ticks were evaluated, until reaching an animal that presented a population of 114 ticks.

The treated group showed an average of 0.30 ticks, 1.06, $1.10,0.70,1.30,1.34$ on days $+7,+14,+21,+28,+35$ and +42 , respectively. The formulation presented acaricidal efficacy of $97.84 \%, 92.36 \%, 92.07 \%, 94.06 \%, 90.63 \%$ and $90.35 \%$ on days $+7,+14,+21,+28,+35$ and +42 , respectively.

When the efficacy of the product was evaluated based on the scale according to the study by Marchiondo et al. (2007)
(Figure 1), the total of animals with infestation between 0 and 1 and the total of animals with infestation between 2 and 3 was different $(p \leq 0.05)$ during the period of the test.

Likewise, when the efficacy throughout the treatment days was compared, it was found that there were no statistical differences from Day +7 to Day +42 ( $\mathrm{p} \leq 0.05)$. Thus, it is possible to affirm that the product was effective until the $42^{\text {th }}$ day of treatment. According to the obtained results, when applied to dogs with established tick infestations, a single topical application of the novel formulation (delivering, at least, $6.7 \mathrm{mg}$ fipronil $/ \mathrm{kg} \mathrm{bw}$ ) was highly efficacious in eliminating $R$. sanguineus for the first seven days. These data presented better results than others performed with other single formulations did. Folz et al. (1986) demonstrated that an amitraz formulation could prevent $R$. sanguineus with $90 \%$ efficacy just for 2 weeks following treatment.

The use of the fipronil formulation alone or combined with other drugs is expected to significantly reduce the potential for the transmission of tick-borne infectious agents carried by $R$. sanguineus or other Ixodid tick species for at least 28 days. Therefore, the obtained result of 42 days of $R$. sanguineus control can prevent dogs in the Amazon Region from anaplasmosis, erlichiosis and other infestations.

According to the results, the novel topical fipronil formulation (FIPR122 Ourofino Animal Health, SP, Brazil) presented a high acaricidal efficacy rate until the $42^{\text {nd }}$ day of treatment. The referred formulation also presented a preventive efficacy keeping the dogs with low infestation levels (Grade 0 and 1) all along the

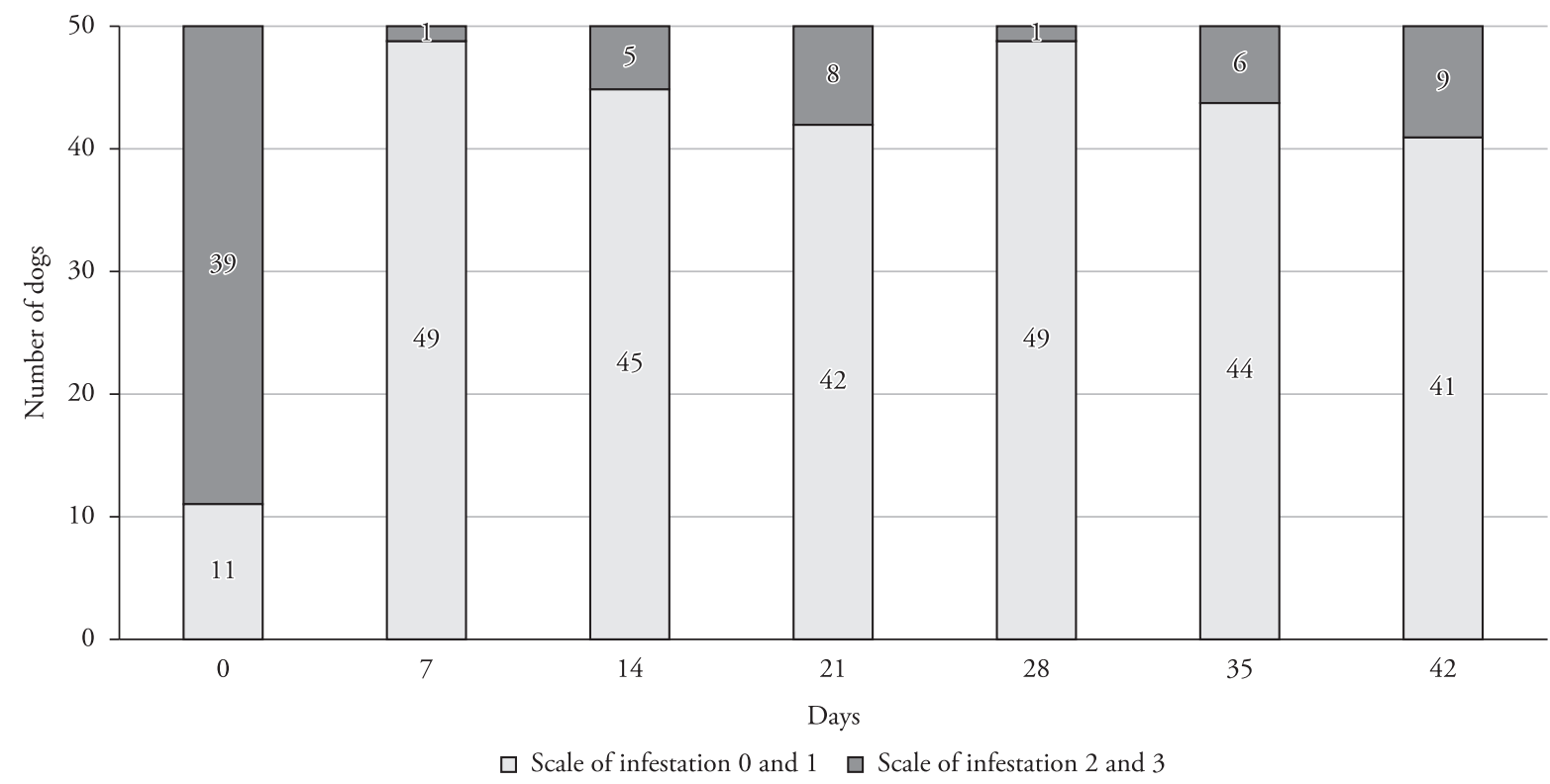

Figure 1. Tick Infestation Scale in the 50 dogs treated with the novel formulation FIPR 122 during 42 days of study, according to Marchiondo et al. (2007).

Table 1. Details of dogs enrolled in the study of acaricidal efficacy of fipronil in dogs in Amazonic region, Brazil.

\begin{tabular}{|c|c|c|c|c|c|c|c|c|c|}
\hline \multirow[b]{2}{*}{ Animals } & \multicolumn{2}{|c|}{ Sex No (\%) } & \multirow{2}{*}{$\begin{array}{l}\text { Age in years } \\
\text { means (range) }\end{array}$} & \multirow{2}{*}{$\begin{array}{l}\text { Bodyweight } \\
\text { in } \mathrm{kg} \text {, mean } \\
\text { (range) }\end{array}$} & \multicolumn{2}{|c|}{ Breed No (\%) } & \multicolumn{2}{|c|}{ Household No (\%) } & \multirow{2}{*}{$\begin{array}{c}\text { Tick infestation } \\
\text { Day 0, Mean } \\
\text { (range) }\end{array}$} \\
\hline & Male & 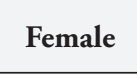 & & & D & Mi & & $\mathbf{R u}$ & \\
\hline Tick Patients & $2(44 \%)$ & $28(56 \%)$ & $3,31(0,25-13)$ & $10,49(2,4-39,1)$ & $28(56 \%)$ & $22(44 \%)$ & $36(72 \%)$ & $14(28 \%)$ & $13,88(3-114)$ \\
\hline
\end{tabular}

No number. \% percentage. 
test, until the $42^{\text {nd }}$ day. Finally, the formulation presented high safety level once no dog presented clinical alterations during the experimental period.

\section{References}

Barros-Battesti DM, Arzua M, Bechara GH. Carrapatos de Importância Médico Veterinária da Região Neotropical: Um Guia Ilustrado para identificação de Espécies. Instituto Butantã; 2006.

Folz SD, Ash KA, Conder GA, Rector DL. Amitraz: a tick and flea repellent and tick detachment drug. J Vet Pharmacol Ther 1986; 9(2): 150-156. PMid:3723659. http://dx.doi.org/10.1111/j.1365-2885.1986. tb00024.x

Grosscurt AC. Factors influencing the acaricidal activity of flucycloxuron. Entomol Exp Appl 1993; 69(3): 201-208. http://dx.doi. org/10.1111/j.1570-7458.1993.tb01742.x

Hunter JS 3rd, Baggott D, Everett WR, Fourie JJ, Cramer LG, Yoon SS, et al. Efficacy of a novel topical combination of fipronil, amitraz and (S)-methoprene for treatment and control of induced infestations of brown dog ticks (Rhipicephalus sanguineus) on dogs. Vet Parasitol 2011; 179(4): 318-323. PMid:21777733. http://dx.doi. org/10.1016/j.vetpar.2011.03.042
Marchiondo AA, Holdsworth PA, Green P, Blagburn BL, Jacobs DE. World Association for the Advancement of Veterinary Parasitology (W.A.A.V.P.) guidelines for evaluating the efficacy of parasiticides for the treatment, prevention and control of flea and tick infestation on dogs and cats. Vet Parasitol 2007; 145(3-4): 332-344. PMid:17140735. http://dx.doi.org/10.1016/j.vetpar.2006.10.028

Paim F, De Souza AP, Bellato V, Sartor AA. Selective control of Rhipicephalus (Boophilus) microplus in fipronil-treated cattle raised on natural pastures in Lages, State of Santa Catarina, Brazil. Rev Bras Parasitol Vet 2011; 20(1): 13-16. PMid:21439225. http://dx.doi.org/10.1590/ S1984-29612011000100003

Pereira CP, De Oliveira PR, Furquim KC, Bechara GH, Camargo-Mathias MI. Fipronil-induced cell death in salivary glands of Rhipicephalus sanguineus (Latreille, 1806) (Acari: Ixodidae) semi-engorged females. Exp Parasitol 2011; 127(2): 481-489. PMid:20974132. http://dx.doi. org/10.1016/j.exppara.2010.10.003

Tancredi MGF, Correia TC, Ribeiro FA, Botelho MCSN, Tavares PV, Scott FB, et al. Eficácia comparativa de duas formulaçóes de uso tópico contendo fipronil 10\% no controle de Ctenocephalides felis felis em gatos. Rev Bras Parasitol Vet 2009; 18(4): 74-77. PMid:20040215. http://dx.doi. org/10.4322/rbpv.01804015

Walker A. Arthropods of domestic animals: A Guide to Preliminary Identification. London: Chapman \& Hall; 1994. 